\title{
Sub-Arctic alpine Vaccinium vitis-idaea exhibits resistance to strong variation in snowmelt timing and frost exposure, suggesting high resilience under climatic change
}

\author{
Friederike Gehrmann $^{1,2}$ - $\cdot$ lida-Maria Lehtimäki ${ }^{1} \cdot$ Heikki Hänninen $^{3} \cdot$ Timo Saarinen $^{1}$
}

Received: 19 April 2019 / Revised: 12 July 2020 / Accepted: 3 August 2020 / Published online: 25 August 2020

(c) The Author(s) 2020

\begin{abstract}
In tundra ecosystems, snow cover protects plants from low temperatures in winter and buffers temperature fluctuations in spring. Climate change may lead to reduced snowfall and earlier snowmelt, potentially exposing plants to more frequent and more severe frosts in the future. Frost can cause cell damage and, in combination with high solar irradiance, reduce the photochemical yield of photosystem II $\left(\Phi_{\mathrm{PSII}}\right)$. Little is known about the natural variation in frost exposure within individual habitats of tundra plant populations and the populations' resilience to this climatic variation. Here, we assessed how natural differences in snowmelt timing affect microclimatic variability of frost exposure in habitats of the evergreen Vaccinium vitis-idaea in sub-Arctic alpine Finland and whether this variability affects the extent of cell damage and reduction in $\Phi_{\mathrm{PSII}}$. Plants in early melting plots were exposed to more frequent and more severe frost events, and exhibited a more pronounced decrease in $\Phi_{\mathrm{PSII}}$, during winter and spring compared to plants in late-melting plots. Snowmelt timing did not have a clear effect on the degree of cell damage as assessed by relative electrolyte leakage. Our results show that sub-Arctic alpine $V$. vitis-idaea is currently exposed to strong climatic variation on a small spatial scale, similar to that projected to be caused by climate change, without significant resultant damage. We conclude that $V$. vitis-idaea is effective in mitigating the effects of large variations in frost exposure caused by differences in snowmelt timing. This suggests that V. vitis-idaea will be resilient to the ongoing climate change.
\end{abstract}

Keywords Chlorophyll fluorescence $\cdot$ Electrolyte leakage $\cdot$ Microclimate $\cdot$ Snowmelt gradient $\cdot$ Tundra

\section{Introduction}

Climate change in northern regions will lead to rising temperatures in winter and changes in the amount of snowfall and the timing of snowmelt (Callaghan et al. 2011; AMAP

Electronic supplementary material The online version of this article (https://doi.org/10.1007/s00300-020-02721-3) contains supplementary material, which is available to authorized users.

Friederike Gehrmann

friederike.gehrmann@umu.se

1 Organismal and Evolutionary Biology Research Programme, Viikki Plant Science Centre, University of Helsinki, Helsinki, Finland

2 Climate Impacts Research Centre, Department of Ecology and Environmental Science, Umeå University, Abisko, Sweden

3 State Key Laboratory of Subtropical Silviculture, Zhejiang A\&F University, Hangzhou, China
2017). In tundra ecosystems, snow cover protects plants from low and fluctuating temperatures, so an advance in snowmelt timing caused by climatic warming potentially exposes plants to more frequent early season frost events. Frost (sub-freezing temperatures), especially during the period of dehardening and growth initiation in spring, can cause cell damage to vegetative and flower buds and stress to the photosystem with consequences at the ecosystem level for pollinators, seed recruitment, growth and carbon cycling (Ensminger et al. 2004; Taulavuori et al. 2004; Inouye 2008; Wipf et al. 2009).

Snow manipulation experiments have been used to study the effect of simulated changes in snowmelt timing on plant physiology (Starr 2001; Starr et al. 2008; Lundell et al. 2010; Taulavuori et al. 2011). These effects can be studied alternatively along natural gradients in snowmelt timing that occur on the scale of a few metres in sub-Arctic alpine ecosystems, due to the effect of wind blow and the uneven topography on the distribution of snow. (Billings and Bliss 1959; McKay and Gray 1981; Ögren 1996; Bokhorst 
et al. 2010, 2017). Spatial heterogeneity in snow cover on a small local scale implies that plants growing in early melting vegetation patches may be exposed to early season frost events, whilst thicker snow cover on late-melting patches insulates plants from low air temperatures until later in the season when temperatures are milder (Kimball et al. 1973). This variation in plant exposure is not reflected in those air temperature measurements used as standard in species distribution models (SDMs). This is because (1) SDMs usually use global climate data with a coarse resolution which does not capture small-scale spatial heterogeneity and (2) such climate data are usually recorded $2 \mathrm{~m}$ above the ground, which does not account for the temperature in the soil or near the ground, especially under the snow (Scherrer and Körner 2010, 2011; Scherrer et al. 2011; Graae et al. 2012; Aalto et al. 2017). Heterogeneous landscapes can harbour future refugia or stepping stones which allow plants to persist in a changing climate by providing suitable microhabitats for survival and migration as the macroclimatic conditions change (Niskanen et al. 2017a, b; Graae et al. 2018). Furthermore, it has been suggested that plant populations exposed to highly variable environments are likely to hold large adaptive potential, which may help them to adapt to new environments in the future (Crawford 2008). Hence, by overlooking microclimatic variability, SDMs risk underestimating the role of phenotypic plasticity for the persistence of a species in a changing climate (Lenoir et al. 2017; Lembrechts et al. 2018).

The risk of frost exposure and the persistence of snow are important determinants of local plant performance in cold ecosystems, as well as influencing regional plant distribution patterns (Inouye 2000; Körner 2003; Niittynen and Luoto 2017). Despite this, small-scale spatial variation in frost exposure at the plant level is not commonly reported in snow gradient studies, even though it can vary significantly within microhabitats. In order to assess the likelihood that certain plant species will be able to persist in their current habitats under future climates, or persist locally in nearby niches, we need information on how much environmental variation is present in their current habitats and how plant populations cope with this variation.

Some species, like the evergreen dwarf shrub Vaccinium vitis-idaea L., exist in a wide range of microclimates and hence a single population may experience a multitude of climatic conditions, which is reflected in its high phenotypic plasticity (Ritchie 1955). With its distribution across polar, boreal and alpine ecosystems, V. vitis-idaea is an important species of ecosystems that are largely snowcovered in winter. Wintertime photosynthesis beneath the snow is well-documented for evergreen dwarf shrubs such as V. vitis-idaea, Ledum palustre and Cassiope tetragona (Starr and Oberbauer 2003; Lundell et al. 2008, 2010; Saarinen and Lundell 2010). Underneath the snow, the conditions can be suitable for photosynthesis when sufficient light penetrates to the leaves and the temperature and moisture conditions are favourable (Neuner et al. 1999; Tahkokorpi et al. 2007; Lundell et al. 2008). Wintertime photosynthesis can even compensate for respiratory losses, as the light compensation point in winter is low (Starr and Oberbauer 2003; Lundell et al. 2008; Saarinen and Lundell 2010; Saarinen et al. 2015). However, compared to the subnivean environment, upon snowmelt in spring, plants are suddenly exposed to high solar radiation and low temperature (Gerland et al. 2000). Due to the low temperature inhibition of photosynthetic electron transport and carbon dioxide uptake, this can create an imbalance between the temperature-insensitive absorption of light energy and the downstream photosynthetic reactions (Öquist and Huner 2003). When more light energy is absorbed by chlorophyll than can be passed down the electron transport chain, the excess energy can cause photooxidative damage (Adams III et al. 2002; Öquist and Huner 2003). Plants possess several mechanisms and structures to avert this risk during unfavourable winter conditions, such as the thermal dissipation (non-photochemical quenching, NPQ) of the photon energy by the photosystem II protein complex and light-harvesting antennae aided by zeaxanthin ( $\mathrm{Li}$ et al. 2000). This mechanism can be activated transiently upon exposure to light during unfavourable conditions (e.g. low temperatures) or it develops during winter hardening (sustained NPQ) and is released in spring upon return to favourable weather conditions (Adams III et al. 2004). Damage to the photosystem II and NPQ both result in a reduced photochemical yield of photosystem II ( $\left.\Phi_{\text {PSII }}\right)$ (Adams III et al. 2002, 2004). Lack of snow cover in winter combined with both low temperatures and high irradiance causes a decrease in $\Phi_{\mathrm{PSII}}$ in sub-Arctic V. vitis-idaea, compared to when it is growing under snow cover (Saarinen and Lundell 2010; Taulavuori et al. 2011). However, we do not know whether the degree of inhibited $\Phi_{\text {PSII }}$ varies amongst individuals of $V$. vitisidaea growing along a natural snowmelt gradient where the plants are exposed to differences in low temperature and high irradiance.

Temperatures below the threshold for freezing resistance can directly damage plant cell membranes. Frost hardiness, or frost survival, in plants changes seasonally and depends on the preceding temperature and moisture conditions, but winter snow cover reduces hardiness (Palacio et al. 2015; Sklenáŕ 2017). The degree of sub-lethal cell damage can be measured as the extent of electrolytes leaking from damaged cells (Bajji et al. 2001). It is not known whether cell damage differs amongst individuals of $V$. vitis-idaea from adjacent microclimate regimes.

In this study, we assessed the extent of spatial and temporal microclimate variability of snowmelt timing and frost exposure and its effect on the leaf photosynthetic 
function and cell damage in V. vitis-idaea in a sub-Arctic environment above the treeline in northern Finland. We hypothesised that

(1) Frost intensity, in terms of the duration and minimum temperature of frost events, increases with earlier day of year (DOY) of snowmelt,

(2) V. vitis-idaea experiences more cell damage and reduced $\Phi_{\text {PSII }}$ in spring shortly after snowmelt compare to summer and

(3) Cell damage and reduction in $\Phi_{\mathrm{PSII}}$ in spring increase with earlier DOY of snowmelt.

We also evaluate whether frost intensity can explain these ecophysiological responses and addressed these hypotheses under consideration of the potentially confounding effects of mountain slope aspect and year of the measurements.

\section{Materials and methods}

\section{Study site}

The study was carried out in sub-Arctic alpine tundra on Saana mountain in Kilpisjärvi, Finland $\left(69^{\circ} 02^{\prime} 37^{\prime \prime} \mathrm{N}, 20^{\circ}\right.$ 51' 22" E) in 2015 and 2016 (Online Resource 1a). For the period 1981-2010, mean monthly air temperatures range from $-12.9^{\circ} \mathrm{C}$ (January) to $11.2^{\circ} \mathrm{C}$ (June) and the mean annual precipitation is $487 \mathrm{~mm}$ (Pirinen et al. 2012). Snowmelt begins in April-May but can last until July in patches with thick snow cover and snow depth can vary by up to $256 \mathrm{~cm}$ within a few metres (Aalto et al. 2018). The vegetation in the study area consists primarily of woody dwarf shrubs such as Empetrum nigrum, Betula nana, Salix spp. and Vaccinium spp. On two mountain slope aspects ('Sites': north-west facing, termed 'North' and south-east facing, termed 'South'), we identified areas with different timing of snowmelt in spring and classified them into three groups based on their sequential melt-out time with respect to each other to cover a wide range of snowmelt timing (Online Resource 1b). These snowmelt categories were termed 'Early', 'Mid' and 'Late' and located at approximately $700-770 \mathrm{~m}$ a.s.l. Within each site, four plots of $2 \mathrm{~m} \times 2 \mathrm{~m}$ were marked per snowmelt group in 2014 for an earlier study (Gehrmann et al. 2018). In total, 21 sample plots were used in the present study with 12 plots on the North site (four in Early, four in Mid and four in Late) and 9 plots on the South site (four in Early, four in Mid and one in Late). We could only select one plot in South-Late as V. vitis-idaea did not occur in the other plots. Plots within the same Site were between 3 and $200 \mathrm{~m}$ apart. A detailed description of the site and study design can be found in Gehrmann et al. (2018).

\section{Temperature measurements and frost severity}

Air temperature at approximately $15 \mathrm{~cm}$ above the ground, soil surface temperature and temperature $10 \mathrm{~cm}$ below the ground (rooting zone) were recorded at hourly intervals with one or two iButtons ${ }^{\circledR}$ (DS1922L-F5 thermochrons; Homechip Ltd., UK) in each plot, so that each plot had between three and six temperature loggers. The temperatures were recorded continuously from spring 2014 until the end of summer in 2016. The air temperature loggers were protected from direct sunlight with cylindrical radiation shields (height $=15 \mathrm{~cm}$, diameter $=6 \mathrm{~cm}$ ) made of white PVC plastic.

The timing of snowmelt was estimated as the day on which the range of daily fluctuations in soil surface temperatures reached at least $5{ }^{\circ} \mathrm{C}$. Precise measurements of snow depth were not possible due to the risk of avalanches in the area, but early melting plots had the least amount of snow and late-melting plots the most.

In order to assess frost intensity, for each plot, each continuous sequence of hourly temperatures below $0{ }^{\circ} \mathrm{C}$ was extracted and constituted one freezing event in the analyses. Multiple events per day were possible. For each freezing event, the duration (number of hours) of the event and its minimum temperature were determined.

\section{Photosynthetic photo flux density}

Photosynthetic photon flux density (PPFD, quantified as the amount of photons in $\mu \mathrm{mol}$ in the range of $400-700 \mathrm{~nm}$ reaching a surface of $1 \mathrm{~m}^{2}$ per second) for Kilpisjärvi was obtained from the STRÅNG model of the Swedish Meteorological and Hydrological Institute (https://strang.smhi.se/), as locally measured data were not available. The model produces hourly PPFD data at a resolution of $2.5 \mathrm{~km} \times 2.5 \mathrm{~km}$ based on calculations of clear sky spectral irradiance coupled with a cloud effect function. The input data for the model are modelled meteorological parameters and satellite ozone observations. For each freezing event, we extracted the highest PPFD ( $\left.\mathrm{PPFD}_{\max }\right)$ modelled during that event. The $\mathrm{PPFD}_{\max }$ during each freezing event was determined to find out whether the number of high irradiance and low temperature events varied along the snowmelt gradient. Based on prior experiments (Lundell et al. 2008), we considered PPFD $_{\max }>500 \mu \mathrm{mol} \mathrm{m}{ }^{-2} \mathrm{~s}^{-1}$ during spring freezing events to be a potentially stressful high-light exposure.

\section{$\Phi_{\text {PSII }}$ measured using chlorophyll fluorescence}

The photochemical quantum yield of photosystem II (darkadapted $\left.\Phi_{\mathrm{PSII}}=F_{\mathrm{v}} / F_{\mathrm{m}}\right)$ in $V$. vitis-idaea was assessed by measuring the ratio of variable $\left(F_{\mathrm{v}}\right)$ to maximum fluorescence $\left(F_{\mathrm{m}}\right)$ in dark-adapted leaves. This ratio is a measure of 
photosystem II stress. The measurements were made in 2015 and 2016 once shortly after snowmelt ('Spring') and once in late July ('Summer', Table 1). In each plot, 24 healthy looking leaves of different shoots from the previous growing season (the second or third leaf from the tip of the shoot) were dark-adapted in leaf clips for 20 min before measuring $F_{\mathrm{v}} / F_{\mathrm{m}}$ with a portable chlorophyll fluorometer (PAM-2100, Walz $\mathrm{GmbH})$. A few measurements where the chlorophyll fluorescence signal was too noisy to confidently determine the $F_{\mathrm{v}} / F_{\mathrm{m}}$ were excluded.

\section{Freezing damage estimated by relative electrolyte leakage}

Relative electrolyte leakage is a measure of cell damage (Sutinen et al. 1992; Luoranen et al. 2004). The relative electrolyte leakage of $V$. vitis-idaea leaves was measured twice both in 2015 and 2016 (Table 1). The first set of measurements was carried out within two weeks after snowmelt ('Spring'), except in early melting plots in 2015 and latemelting plots in 2016 in the South, where the measurements were made three to four weeks after snowmelt. In each year, the second set of measurements was carried out in July
('Summer') on the same or consecutive days within the same site. In late-melting plots, no second set of measurements was made in 2015.

From each plot, we collected 72 healthy looking leaves from the previous growing season (the second or third leaf from the tip of the shoot; different leaves to those used for chlorophyll fluorescence) evenly across the plot in sample boxes containing moist tissue paper and stored them at $4{ }^{\circ} \mathrm{C}$ until the measurements were carried out on the same or the following day. We pooled the leaves into samples of three leaves (i.e. 24 samples per plot) and cut each leaf into six evenly sized pieces. Each sample was placed in a separate $50 \mathrm{~mL}$ Eppendorf tube and rinsed with approximately $15 \mathrm{~mL}$ distilled water. The leaves were then incubated in $20 \mathrm{~mL}$ of fresh distilled water and shaken at $100 \mathrm{rpm}$ for $14 \mathrm{~h}$. Subsequently, the tubes were boiled for $60 \mathrm{~min}$ to kill the plant cells. The conductivity of each sample was measured with a conductivity probe (Hanna Instruments, Inc.) before and after boiling, the latter after the samples had reached room temperature. To account for spontaneous ionisation of pure water, the conductivity of control samples containing only $20 \mathrm{~mL}$ of deionised water was subtracted from each sample measurement. The relative electrolyte leakage was calculated as the ratio of conductivity
Table 1 Estimated date of snowmelt timing (number of plots in parentheses) and date of electrolyte leakage and chlorophyll fluorescence measurements of Vaccinium vitis-idaea at two mountain slope aspects (North and South) and three groups of snowmelt timing (Early, Mid and Late) above the treeline on mount Saana, Kilpisjärvi, in 2015 and 2016

\begin{tabular}{|c|c|c|c|c|c|}
\hline & \multirow[t]{3}{*}{ Date of snowmelt } & \multicolumn{4}{|c|}{ Date of measurements } \\
\hline & & \multicolumn{2}{|c|}{ Chlorophyll fluorescence } & \multicolumn{2}{|c|}{ Electrolyte leakage } \\
\hline & & Spring & Summer & Spring & Summer \\
\hline \multicolumn{6}{|l|}{2015} \\
\hline \multicolumn{6}{|l|}{ North } \\
\hline Early $(n=4)$ & 19 May-26 May & $\begin{array}{l}23 \text { May } \\
29 \text { May }\end{array}$ & 24 July & $\begin{array}{l}24 \text { May } \\
27 \text { May } \\
30 \text { May }\end{array}$ & $\begin{array}{l}29 \text { July } \\
30 \text { July }\end{array}$ \\
\hline $\operatorname{Mid}(n=4)$ & 01 June-06 June & $\begin{array}{l}\text { 04 June } \\
\text { 07 June }\end{array}$ & 24 July & $\begin{array}{l}\text { 02 June } \\
12 \text { June }\end{array}$ & $\begin{array}{l}29 \text { July } \\
30 \text { July }\end{array}$ \\
\hline Late $(n=4)$ & 26 June-29 June & 04 July & 24 July & NA & 31 July \\
\hline \multicolumn{6}{|l|}{ South } \\
\hline Early $(n=4)$ & 22 April-11 May & $\begin{array}{l}25 \text { May } \\
28 \text { May }\end{array}$ & 23 July & $\begin{array}{l}23 \text { May } \\
29 \text { May }\end{array}$ & 01 August \\
\hline $\operatorname{Mid}(n=4)$ & 26 May-30 May & 03 June & 23 July & $\begin{array}{l}29 \text { May } \\
\text { 02 June }\end{array}$ & 01 August \\
\hline Late $(n=1)$ & 08 June & 10 June & 23 July & NA & 01 August \\
\hline \multicolumn{6}{|l|}{2016} \\
\hline \multicolumn{6}{|l|}{ North } \\
\hline Early $(n=4)$ & 30 April-04 May & 14 May & 19 July & 12 May & 25 July \\
\hline $\operatorname{Mid}(n=4)$ & 29 April-06 May & 14 May & 19 July & 15 May & 25 July \\
\hline Late $(n=4)$ & 27 May-11 June & $\begin{array}{l}06 \text { June } \\
15 \text { June }\end{array}$ & 19 July & $\begin{array}{l}\text { 04 June } \\
06 \text { June } \\
16 \text { June }\end{array}$ & 25 July \\
\hline \multicolumn{6}{|l|}{ South } \\
\hline Early $(n=4)$ & 28 April-30 April & 13 May & 15 July & 14 May & 23 July \\
\hline $\operatorname{Mid}(\mathrm{n}=4)$ & 29 April-01 May & 13 May & 15 July & 17 May & 23 July \\
\hline Late $(n=1)$ & 15 May & 04 June & 15 July & 01 June & 23 July \\
\hline
\end{tabular}


before boiling to that after boiling and converted to percentage. Further details of the method can be found in Lundell et al. (2008).

\section{Statistical analyses}

For the following statistical analyses, we used the actual date of snowmelt timing (SnowmeltDOY) of each plot instead of the category of snowmelt (Early, Mid, Late) to achieve a better representation of the continuous gradient in snowmelt timing at the study site.

We tested whether the duration and minimum temperature of each freezing event varied significantly between years (2015, 2016), sites (North, South), seasons (spring, summer) and the DOY of snowmelt timing (SnowmeltDOY) using a linear mixed model with Plot as a random effect and a weighted variance for SnowmeltDOY, the latter to improve homogeneity of residuals. We used the log-likelihoods to compare nested models and only retained variables in the final model which significantly $(p<0.05)$ improved the likelihood ratio. The significance of individual covariates was assessed with an $F$-test applied to the restricted maximum likelihood estimates of the model.

Akaike's information criterion (AIC) was used to evaluate whether Season (Spring and Summer), Site (North and South) or SnowmeltDOY or a combination of those, were good predictors of relative electrolyte leakage and of $F_{\mathrm{v}} / F_{\mathrm{m}}$. For this, we fitted mixed effect maximum likelihood models with either of the three factors, or interactions amongst them, as explanatory variables. Relative electrolyte leakage (REL [\%]) or $F_{\mathrm{v}} / F_{\mathrm{m}}$, was the response variable and Plot was a random effect in the model. The model with the lowest $A I C$ value was considered to have the best fit. Models were fitted to each year separately due to different timing of the measurements during the two years. An $F$-test was applied to the best-fit model (with restricted maximum likelihood estimates) to test the significance $(p<0.05)$ of the effects of the individual variables and their interactions. Pairwise comparisons were carried out with the emmeans package (Lenth 2020, version 1.4.6). The assumptions of normality, independence and homogeneity of variance of the residuals was confirmed with visual assessment of standard residual plots. A weighted variance function was applied to one or several factors if these assumptions were not met. We used the lme function in the nlme package version 3.1-147 (Pinheiro et al. 2020) for fitting the models. All analyses and figures were made in $\mathrm{R}$ version 4.0.0 (Pinheiro et al. 2020; R Core Team 2020).

\section{Results}

\section{Snowmelt timing and temperature conditions at the plant level}

In 2015, the early melting plots became snow-free between 22 April and 26 May, the mid-melting plots between 26 May and 06 June and the late-melting plots between 08 and 29 June (Table 1). In 2016, an unusually warm period at the end of April caused plots classified as early or mid melting to melt out at about the same time, between 28 April and 06 May (Table 1). Late-melting plots became snow-free between 15 May and 11 Jun in 2016. South plots melted out before North plots within the same snowmelt timing.

In early and mid-melting plots, air temperatures at $15 \mathrm{~cm}$ above the ground ranged between -5 and $-20{ }^{\circ} \mathrm{C}$ and fluctuated by more than ten degrees within a single day during the winter months (January-May; Fig. 1, only data from North site shown). Late-melting plots retained air temperatures at $15 \mathrm{~cm}$ above the ground between 0 and $-5{ }^{\circ} \mathrm{C}$ from January until the snow melted, with the exception of a few colder days (Fig. 1). In comparison, air temperature measured at the weather station in Kilpisjärvi (ca. $1.5 \mathrm{~km}$ from the study site and $500 \mathrm{~m}$ a.s.1.) fluctuated more than those at our plots in the winter, reaching a minimum of $-37{ }^{\circ} \mathrm{C}$, and weather station temperature was generally lower in the summer than the canopy-level air temperature measurements (Fig. 1).

In early and mid-melting plots, the soil surface temperature followed the fluctuations of the air temperature during January-May, with the coldest temperature being $-13{ }^{\circ} \mathrm{C}$ (Fig. 1). In the late-melting plots, the soil surface temperature was always above $-2{ }^{\circ} \mathrm{C}$, apart from the cold days in February where it was $-3.7^{\circ} \mathrm{C}$ at the coldest. Soil surface temperature in late-melting plots was decoupled from the air temperature fluctuations until snowmelt.

In late-melting plots, especially in the South, the rooting zone temperature was often above freezing already before the snow melted and it never dropped below $-5{ }^{\circ} \mathrm{C}$ after January (data from South site not shown). In all of the other plots, the rooting zone temperature fluctuated considerably during the winter and reached down to $-14{ }^{\circ} \mathrm{C}$, with lower temperatures occurring usually in plots on the North site. In all plots, rooting zone temperatures remained around $0{ }^{\circ} \mathrm{C}$ during melt-out due to the constant heat transfer between meltwater and the frozen soil water, termed the zero curtain effect (Outcalt et al. 1990). A fast rise in the rooting zone temperatures above $0{ }^{\circ} \mathrm{C}$, alongside its increased fluctuation above freezing, took place simultaneously with the estimated dates of snowmelt timing (Fig. 1 and Table 1). 


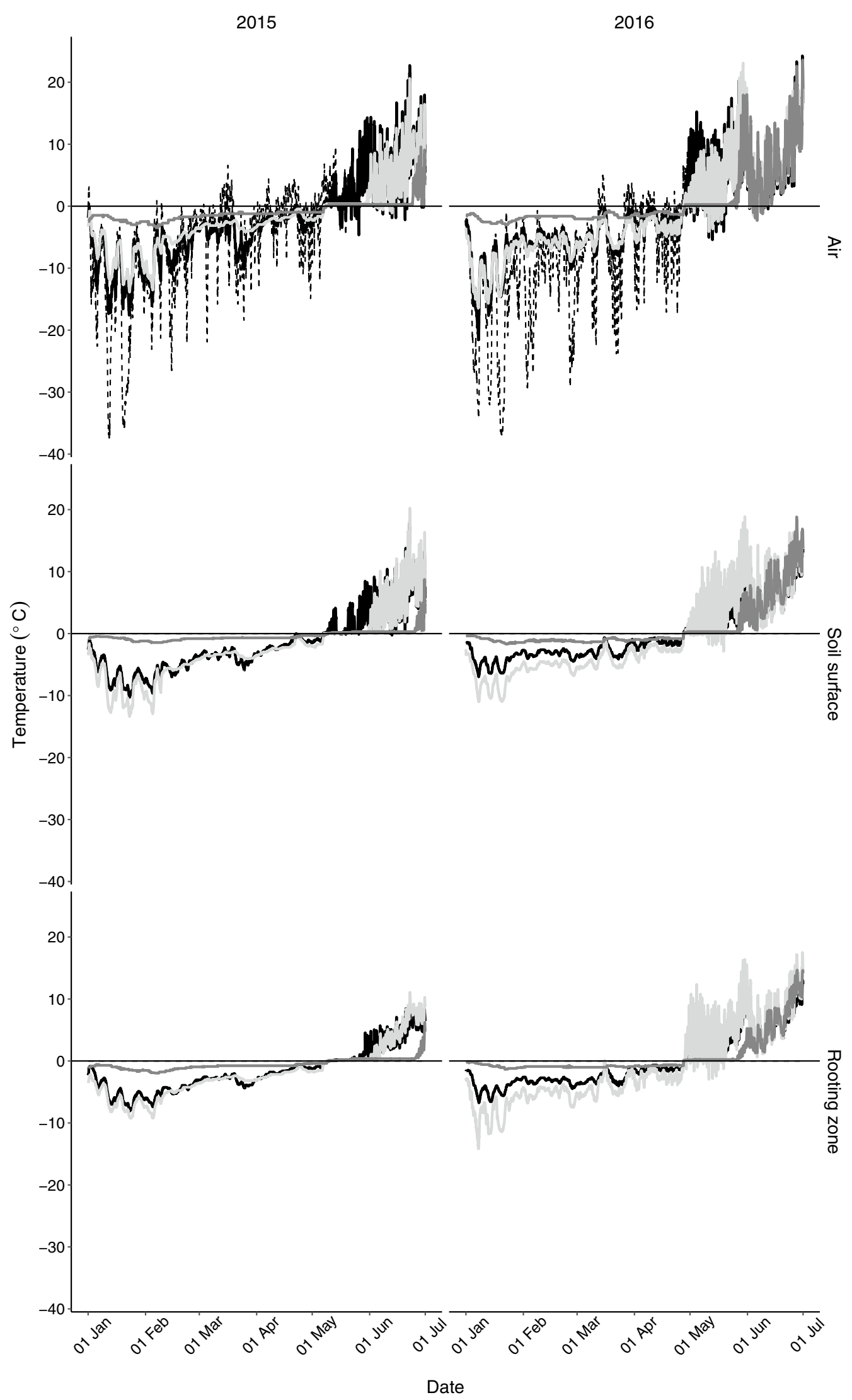


4Fig. 1 Average air, rooting zone and soil surface temperatures in 2015 and 2016 at the North site in plots with early (black), mid- (light grey) or late-melting (dark grey) snow above the treeline on mount Saana, Kilpisjärvi. In the air temperature panel, weather station temperatures in Kilpisjärvi are presented (black dashed line)

\section{Frost intensity}

In line with our first hypothesis, frost intensity decreased significantly towards later snowmelt dates. From earliest to latest snowmelt DOY, the mean number of frost events decreased from 43 to 0 (data not shown), the frost event duration from 17 to $0 \mathrm{~h}$ (SnowmeltDOY $F_{1,710}=133.096$, $p<0.0001$, Fig. 2a) and the mean minimum temperature of frost events from -11.3 to $-0.2{ }^{\circ} \mathrm{C}$ (SnowmeltDOY $F_{1,711}=239.0232, p<0.0001$, Fig. 2b). Freezing duration was significantly higher in the South site compared to the North site, although the difference was small and only present in spring (effect size $1.3 \mathrm{~h}, p=0.0178$ ). In the South site, freezing duration in summer was $1.5 \mathrm{~h}$ less than in spring $(p<0.0001)$. Apart from SnowmeltDOY, minimum freezing temperature was only significantly affected by season where it was marginally higher in the summer (effect size $\left.0.3{ }^{\circ} \mathrm{C}, p=0.0001\right)$.

Exceptionally long and cold freezing events occurred on the south-facing slope in early melting plots in 2015 shortly after snowmelt (Fig. 3). Freezing events there lasted up to $17 \mathrm{~h}$ with a minimum temperature of $-11.3^{\circ} \mathrm{C}$. In 2016 , early and mid-melting plots were exposed to much more similar freezing events than in 2015 , as both melted out on similar dates (Fig. 3).

\section{Concomitant high irradiance and low temperature events}

During the freezing events occurring after snowmelt, the highest received irradiance $\left(\mathrm{PPFD}_{\max }\right)$ was $685 \mu \mathrm{mol} \mathrm{m} \mathrm{m}^{-2} \mathrm{~s}^{-1}$ (Online Resource 2). Some freezing temperatures occurred during the night early in spring, so the lowest PPD $_{\max }$ was $0 \mu \mathrm{mol} \mathrm{m} \mathrm{m}^{-2} \mathrm{~s}^{-1}$. Low temperature events with concomitant high irradiance were only present in early melting plots in the South site in 2015 (marked with a red asterisk in Fig. 3).

\section{Chlorophyll fluorescence}

Chlorophyll fluorescence was best explained by the interaction of Season with Site and Season with SnowmeltDOY in 2015 and by the interaction of Season, Site and SnowmeltDOY in 2016 (Online Resource 3). In accordance with our hypothesis 2 , the combined mean $F_{\mathrm{v}} / F_{\mathrm{m}}$ (chlorophyll fluorescence of photosystem II) in $V$. vitis-idaea was higher in the summer $(0.75 \pm 0.01, n=42)$ than in spring $(0.40 \pm 0.01$, $n=42$ ) (Fig. 4). This difference was statistically significant in both 2015 and 2016 as a main effect (Table 2) and within each Site (Online Resource 3 ). In 2015, $F_{\mathrm{v}} / F_{\mathrm{m}}$ increased by 0.004 per day of delay in snowmelt in spring and increased correspondingly by 0.0002 per day of delay in snowmelt in summer, which was according to our hypothesis 3 . In $2016, F_{\mathrm{v}} / F_{\mathrm{m}}$ also increased with later snowmelt in spring, by 0.002 and 0.012 per day of later snowmelt in the North and South site, respectively, but in the South site in summer it decreased by 0.002 per day of later snowmelt delay (Table 2, Fig. 4).

\section{Relative electrolyte leakage}

Relative electrolyte leakage (REL) was best explained by the two-way interactions of Season, Site and SnowmeltDOY in 2015 and by Season in 2016 (Online Resource 3). Electrolyte leakage was always significantly higher in summer compared to spring, but only by $2.4 \%\left(F_{1,875}=4.4255\right.$, $p=0.0357)$ and $0.7 \%\left(F_{1,736}=309.2752, p=<0.0001\right)$ in 2015 and 2016, respectively (Fig. 5, Table 2, Online Resource 3). The effect of snowmelt timing (SnowmeltDOY) found in 2015 was opposite in the two sites. Relative electrolyte leakage decreased with later snowmelt timing in the North site and increased with later snowmelt timing in the South site. These results only partially agree with our hypotheses 2 and 3 , that REL would be higher in spring than in summer (the measured difference was very small) and higher in spring after earlier compared to later snowmelt (this was only observed in 2015 in the North site).

\section{Discussion}

\section{Microclimate determines frost exposure on a small spatial scale}

Our small-scale temperature measurements along a snowmelt gradient show that spatial variability in the microclimate is high in this tundra ecosystem and is decoupled from the regional conditions. This leads to a large discrepancy between the air temperatures in the winter near the plant canopy under snow and air temperatures measured at the weather station. The microtopography of the landscape causes large gradients in snowmelt timing on the scale of a few metres, which exposes plants to a spatially highly variable environment (Scherrer and Körner 2010; Aalto et al. 2017; Graae et al. 2018). The earliest melting plots melted out up to seven weeks before the latest melting plots, which is similar to the $20 \%$ decrease in the length of snow cover duration predicted for this region in 2071-2100 (Jylhä et al. 2009). Along the snowmelt gradient, the number of freezing events after snowmelt decreased by $95 \%$ from the earliest to the latest melting plots, with some plots being exposed to 
Fig. 2 The a duration and $\mathbf{b}$ minimum freezing temperature of freezing events (continuous periods of sub-zero temperatures) after snowmelt along a gradient of snowmelt timing at two different sites $($ North $=$ solid symbols, South = open symbols). Freezing events were classified as Spring (black), if they occurred before the spring plant ecophysiological measurements, or Summer (grey), if they occurred after the spring plant measurements (see main text and Fig. 3 for further clarification). The lines $($ North $=$ solid, South $=$ dotted $)$ represent the modelled regression. The symbols represent the categories of snowmelt timing in Gehrmann et al. (2018) $($ Early $=$ circle, $\mathrm{Mid}=$ triangle, Late $=$ square)

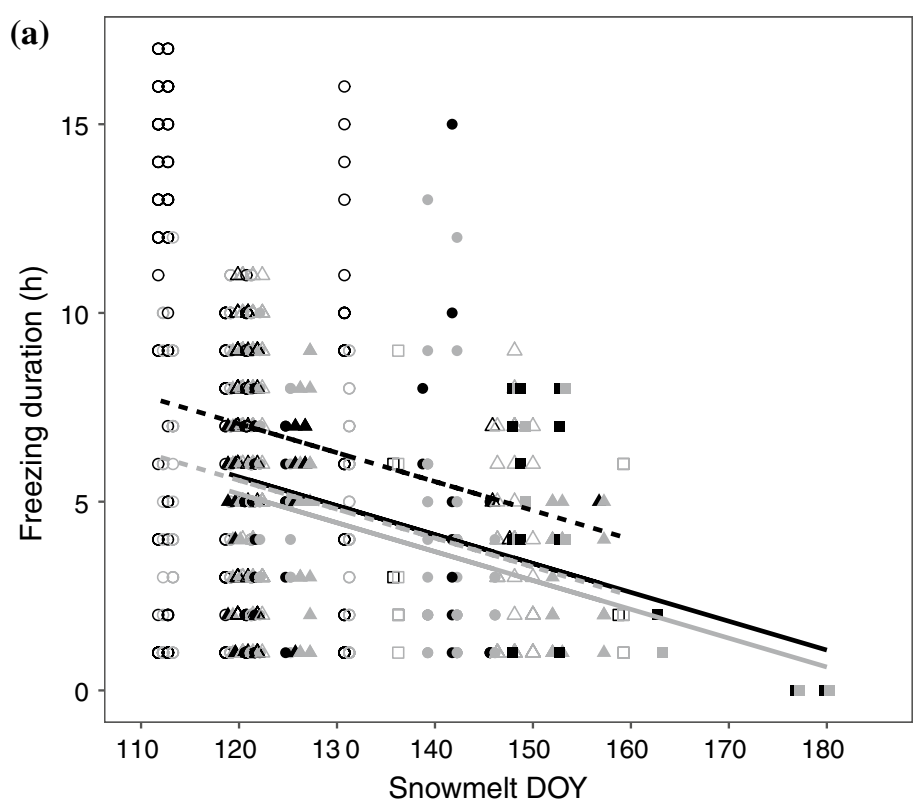

Site

- North

- - South

Site-Snowmelt

- North-Early

o South-Early

- North-Mid

$\triangle$ South-Mid

- North-Late

口 South-Late

Season

$\rightarrow$ Spring

- Summer

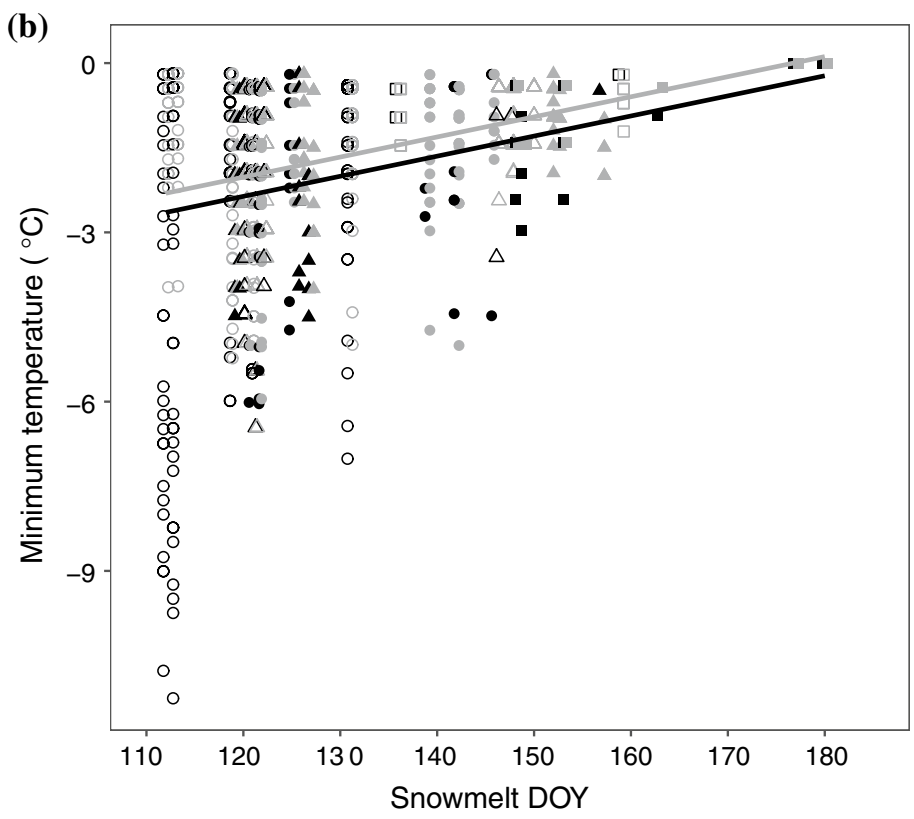

Site-Snowmelt

- North-Early

O South-Early

A North-Mid

$\Delta$ South-Mid

- North-Late

口 South-Late

Season

- Spring
- Summer no freezing events at all after snowmelt (Fig. 3). This difference in freezing events is considerably higher than the $30 \%$ reduction in the number of freezing days predicted for the period 2071 to 2100 in northern Finland (Jylhä et al. 2009). In a snow manipulation experiment in sub-Arctic Alaska, the number of frost days decreased by only $45 \%$ in late-melting plots compared to control plots (Wipf et al. 2006), which is not similar to the natural variation we found here. Our study also shows that the exposure to frost largely depends on the timing of snowmelt, which is highly dependent on microtopography, snowfall and spring temperature. Changes in the timing of snowmelt are difficult to predict, especially due to the uncertainty in expected cloud cover (Rosenfeld et al. 2014), and because microtopography is highly heterogeneous in alpine areas, the actual future frost exposure of sub-Arctic alpine plants may not correspond to the general regional predictions. This highlights the need for detailed quantitative data of microclimatic variation along local environmental gradients (Graae et al. 2012), such as we have reported here.

The risk of frost exposure is an important determinant of plant distribution in cold ecosystems. Plants occurring in these ecosystems have acquired traits which either confer avoidance or tolerance of frost damage (Inouye 2000; Körner 2003). Vaccinium vitis-idaea has successfully established itself along the whole snowmelt gradient in our study site, 


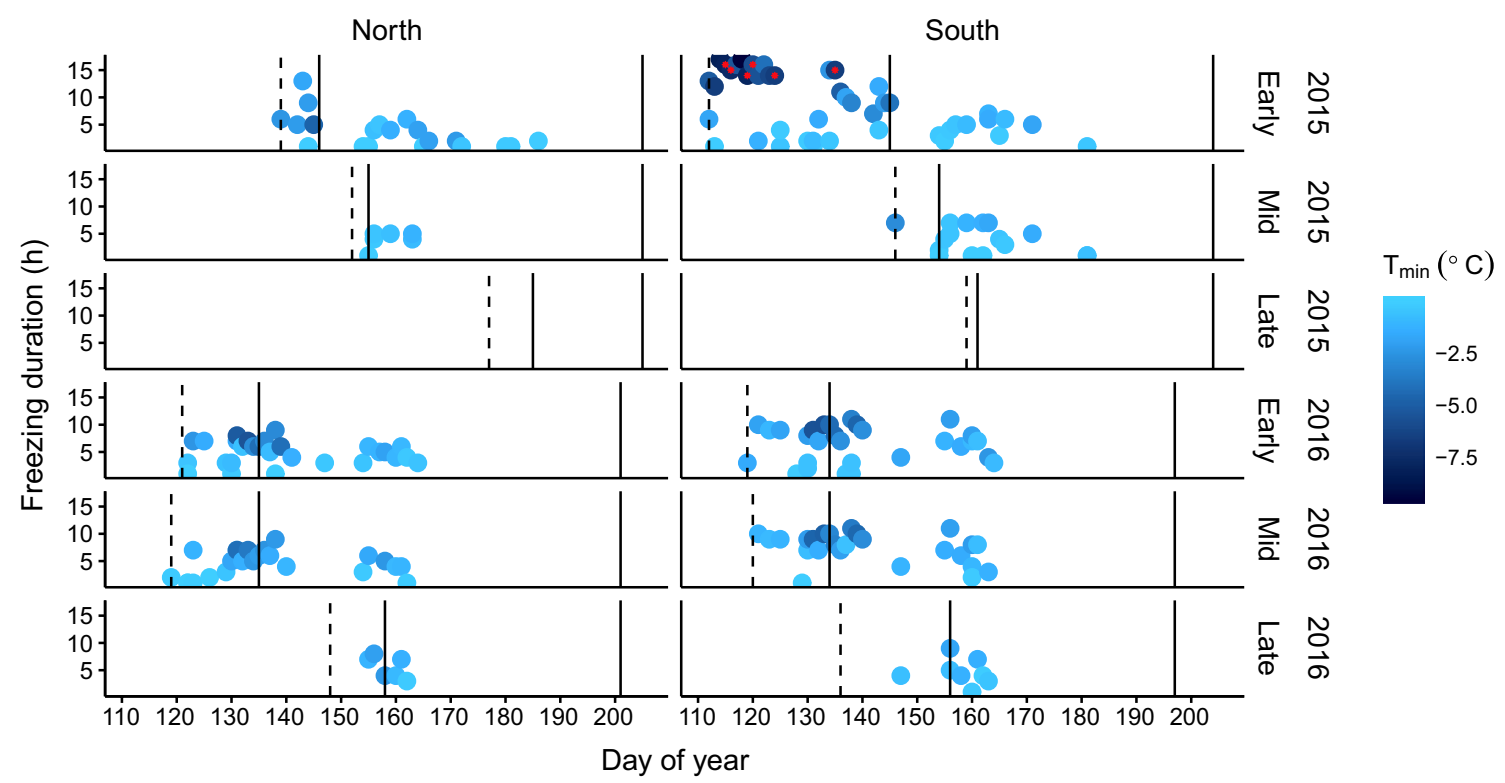

Fig. 3 Average duration and minimum temperature of each freezing event (continuous period during which the air temperature was below $0{ }^{\circ} \mathrm{C}$, in greyscale) after snowmelt in 2015 and 2016 at two mountain slope aspects (North and South) in plots with early, midor late-melting snow above the treeline on mount Saana, Kilpisjärvi. The dashed line indicates the first day of snowmelt, the first solid line from the left indicates the day of year of the first spring $F_{\mathrm{v}} / F_{\mathrm{m}}$

so it must be well adapted to cope with the present variation in frost risk. In this species, the phenological development starts late compared to co-occurring species, and this may represent a strategy allowing the evergreen leaves to cope with early season frost events and its new leaves and flowers to emerge only once frost events are rarer and less severe (Gehrmann et al. 2018). Actively differentiating and young tissues are usually more sensitive to frost than older tissues, so delaying growth until conditions are benign can be an advantage (Inouye 2000).

Apart from a stable, topographically controlled microclimate, sudden weather changes can also temporarily affect the microclimate at a particular site. Warming events during winter are common across Arctic and sub-Arctic areas and are predicted to become more frequent and more severe in the future (see Vikhamar-Schuler et al. 2016 and references therein). During our study period in 2016, one of these unusual winter warming events occurred. The air temperature rose above $5{ }^{\circ} \mathrm{C}$ between the end of April and the beginning of May and reached $8.9^{\circ} \mathrm{C}$ during this period (Fig. 1). In comparison, the average maximum April temperature during the normal period (1981-2010) is 0 to $2{ }^{\circ} \mathrm{C}$ for the region (Pirinen et al. 2012) and during the same period in April 2015 the temperature remained below $4{ }^{\circ} \mathrm{C}$. The warming event caused rapid snowmelt, which led our mid-melting plots to melt out unusually early in 2016, creating a similar microclimate as in the early melting plots. Warming events measurements in the spring and the second solid line the day of year of the first summer $F_{\mathrm{v}} / F_{\mathrm{m}}$ measurements. Measurement dates were similar for relative electrolyte leakage. For all measurement dates see Table 1. Freezing events with a maximum PPFD $>500 \mu \mathrm{molm}^{-2} \mathrm{~s}^{-1}$ are marked with a red asterisk. A colour version of the figure is available online with the minimum freezing temperature in blue shading

like this can lead to the sudden exposure of plants to freezing temperatures when the usual seasonal cold returns, as was the case in the early and mid-melting plots in our study. In vascular plants, the effect of such events varies with species, but in general, plants show reduced flower abundance, reduced reproductive success, reduced shoot and root growth and delayed bud burst (Bokhorst et al. 2009, 2011; Semenchuk et al. 2013). In one study, V. vitis-idaea suffered 51\% shoot mortality after simulated winter warming events, but its growth, reproduction and phenology were not affected (Bokhorst et al. 2011). In our study, V. vitis-idaea usually had delayed vegetative and reproductive bud burst in midcompared to early-melting plots, but the extreme warming event in 2016 advanced the development in mid-melting plots compared to previous years, leading to synchronised bud burst across these plots in 2016 (Gehrmann et al. 2018). Despite the advanced phenological development in the midmelting plots in 2016, we did not see any visible damage to $V$. vitis-idaea in these plots.

\section{Dynamics of $\Phi_{\text {PSII }}$ after snowmelt}

Springtime decrease in $\Phi_{\mathrm{PSII}}$ in $V$. vitis-idaea was evident along the entire snowmelt gradient as shown by the low $F_{\mathrm{v}} / F_{\mathrm{m}}$ ratio shortly after snowmelt in spring compared to the $F_{\mathrm{v}} / F_{\mathrm{m}}$ ratio in July (Fig. 4). In V. vitis-idaea, the photochemical yield of PSII is typically high in leaves under 
Fig. 4 The potential quantum yield $\left(F_{\mathrm{v}} / F_{\mathrm{m}}\right)$ of photosystem II in Vaccinium vitis-idaea (mean $\pm \mathrm{SE}$ ) along a continuous gradient of snowmelt timing (SnowmeltDOY) during spring (measured shortly after snowmelt, black) and summer (measured in July, grey) above the treeline on mount Saana, Kilpisjärvi. Measurements were taken at two different mountain slope aspects (North and South sites) in a 2015 and b 2016. The lines represent the modelled regression line for each site and season. The symbols represent the categories of snowmelt timing in Gehrmann et al. (2018) $($ Early $=$ circle, $\mathrm{Mid}=$ triangle, Late $=$ square)
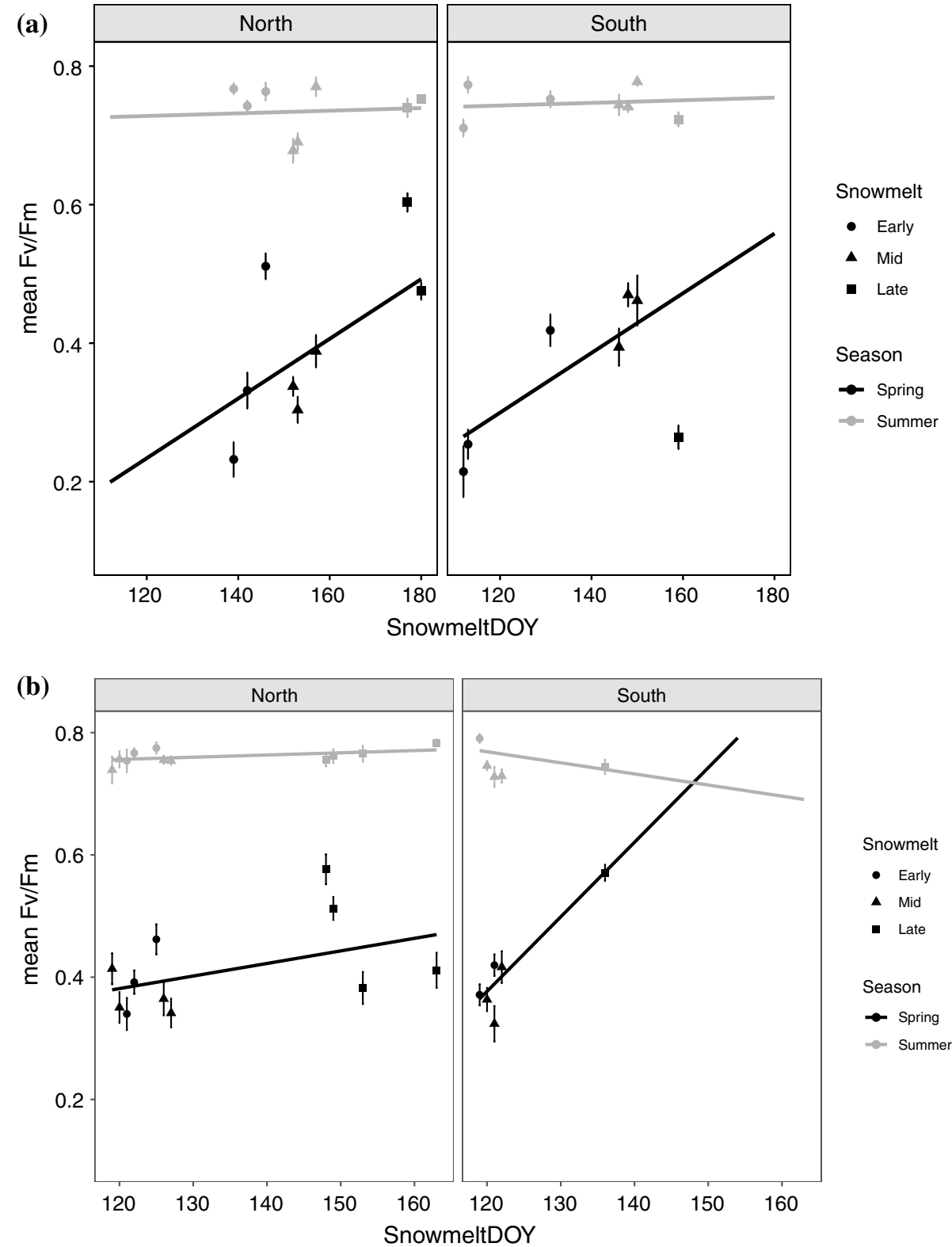

snow cover in winter and starts declining when the snow depth has decreased to less than $20 \mathrm{~cm}$, indicating that there is no sustained wintertime NPQ in response to frost hardening (Lundell et al. 2008). Upon snowmelt, the photochemical yield of PSII drops substantially and exhibits a slow recovery over several weeks, which is thought to be associated with increased thermal dissipation in response to cold temperatures and high-light exposure (Lundell et al. 2008; Solanki et al. 2019). Therefore, the springtime drop in $\Phi_{\mathrm{PSII}}$, which we observed a few days up to a couple of weeks after snowmelt along the whole gradient, likely reflects a strategy of $V$. vitis-idaea to adjust the photosynthetic apparatus to the early spring conditions (Huner et al. 1993). This indicates that $V$. vitis-idaea successfully mitigates the exposure to unfavourable spring conditions regardless of snowmelt timing, allowing full recovery of the potential yield of PSII to $c$. 0.80 by the summer (Maxwell and Johnson 2000; Starr 2001; Lundell et al. 2008).

In a review of photoinhibition (one of the components of NPQ) in plants from different environments, Míguez et al. (2015) found a temperature dependency of cold-induced photoinhibition during winter, suggesting that it is determined by minimum temperatures specifically rather than freezing days in general. In shrubs in particular, $\Phi_{\text {PSII }}$ was reduced by $75 \%$ when the mean winter temperature was below $0{ }^{\circ} \mathrm{C}$. This is comparable to the approximately $50 \%$ reduction in $\Phi_{\text {PSII }}$ which we found in the early melting plots of the snowmelt gradient in the spring in connection with the occurrence of freezing events, as compared to the $\Phi_{\text {PSII }}$ measured in summer, when temperatures were already above 
Table 2 Results from ANOVA of linear mixed-effect models testing the effect of Season (Spring, Summer), Site (North, South), and SnowmeltDOY on the chlorophyll fluorescence and electrolyte leakage in Vaccinum vitis-idaea growing above the treeline on mount Saana, Kilpisjärvi, in 2015 and 2016

\begin{tabular}{|c|c|c|c|}
\hline Explanatory variables & $d f$ & $F$ value & $p$ value \\
\hline \multicolumn{4}{|l|}{ Chlorophyll fluorescence $\left(F_{\mathrm{v}} / F_{\mathrm{m}}\right)$} \\
\hline \multicolumn{4}{|l|}{2015} \\
\hline Season & 1. 846 & 2823.0590 & $<0.0001$ \\
\hline Site & 1. 18 & 1.6162 & 0.2198 \\
\hline SnowmeltDOY & 1. 18 & 5.9461 & 0.0253 \\
\hline Season $\times$ Site & 1.846 & 8.5665 & 0.0035 \\
\hline Season $\times$ SnowmeltDOY & 1.846 & 85.9081 & $<0.0001$ \\
\hline \multicolumn{4}{|l|}{2016} \\
\hline Season & 1.827 & 3261.689 & $<0.0001$ \\
\hline Site & 1.17 & 0.021 & 0.8866 \\
\hline SnowmeltDOY & 1.17 & 1.314 & 0.2675 \\
\hline Season $\times$ Site & 1.827 & 0.208 & 0.6483 \\
\hline Season $\times$ SnowmeltDOY & 1.827 & 26.183 & $<0.0001$ \\
\hline Site $\times$ SnowmeltDOY & 1. 17 & 0.059 & 0.8115 \\
\hline Season $\times$ Site $\times$ SnowmeltDOY & 1.827 & 39.234 & $<0.0001$ \\
\hline \multicolumn{4}{|l|}{ Electrolyte leakage (REL) } \\
\hline \multicolumn{4}{|l|}{2015} \\
\hline Season & 1.736 & 309.2752 & $<0.0001$ \\
\hline SnowmeltDOY & 1.17 & 1.7608 & 0.2021 \\
\hline Site & 1.17 & 4.6516 & 0.0456 \\
\hline Season $\times$ SnowmeltDOY & 1.736 & 60.7012 & $<0.0001$ \\
\hline Season $\times$ Site & 1.736 & 99.5590 & $<0.0001$ \\
\hline Site $\times$ SnowmeltDOY & 1.17 & 6.5475 & 0.0203 \\
\hline \multicolumn{4}{|l|}{2016} \\
\hline Season & 1.875 & 4.4255 & 0.0357 \\
\hline
\end{tabular}

The models with the lowest AIC values are presented here

$0{ }^{\circ} \mathrm{C}$. In the later melting plots, the high $F_{\sqrt{ }} / F_{\mathrm{m}}$ in spring was related to few or no freezing events so that only a $40 \%$ reduction compared to summer values was observed. In the South site in 2015 , late-melting plots had the lowest $F_{\sqrt{ }} / F_{\mathrm{m}}$ in spring. Lundell et al. (2010) have shown that photoinhibition in $V$. vitis-idaea in the same region already begins when the snow cover becomes thinner due to melting and this decrease in $F_{\sqrt{ }} / F_{m}$ continues during the first four days after snowmelt. This was the likely reason also for our observations in the late-melting plots in the South in 2015. The higher $F_{v} / F_{m}$ measured in mid-melting plots in the South site in Spring 2015 may be due to the low number of freezing events prior to the measurements, which have enabled faster recovery. This contrasts with occasions where additional freezing events have slowed down the recovery of $\Phi_{\mathrm{PSII}}$ during spring in the boreal Scots pine and in V. vitis-idaea in southern Finland (Ensminger et al. 2004, 2008; Lundell et al. 2010).

Freezing events during which PPFD was higher than $500 \mu \mathrm{mol} \mathrm{m}{ }^{-2} \mathrm{~s}^{-1}$ did not appear to determine the observed differences in $\Phi_{\mathrm{PSII}}$ as these events only occurred in early melting plots in the South site in 2015. However, based on Lundell et al. $(2008,2010)$, the rate of photosynthesis in $V$. vitis-idaea can become saturated at light intensities much lower than $500 \mu \mathrm{mol} \mathrm{m}{ }^{-2} \mathrm{~s}^{-1}$, so this threshold can be considered a conservative estimate of light intensities which can decrease $\Phi_{\mathrm{PSII}}$ during freezing temperatures.

\section{Leaf damage}

Electrolyte leakage in the North was approximately $10 \%$ higher in summer compared to spring of 2015, but otherwise it was similar amongst sites (c. 30\%) to that found in other such studies throughout the spring (Fig. 5) (Saarinen and Lundell 2010; Preece and Phoenix 2013). This was contrary to our expectation that electrolyte leakage would be higher in spring than in summer due to the occurrence of spring freezing events, which could cause cell damage. This suggests that approximately $30 \%$ is a natural amount of electrolyte leakage in $V$. vitis-idaea in the sub-Arctic tundra in Fenno-Scandinavia during spring. (Saarinen and Lundell 2010; Preece and Phoenix 2013).

Vaccinium vitis-idaea retains frost resistance to approximately $-6{ }^{\circ} \mathrm{C}$ even in a dehardened state at the end of August (Taschler and Neuner 2004; Sklenár 2017). However, the temperature of frost resistance is often defined as the temperature at which $50 \%$ mortality occurs, so sub-lethal damage is not accounted for in measures of frost resistance. This may be the reason why the electrolyte leakage values we found in the summer were higher than we expected based on the frost resistance estimated from mortality. Furthermore, V. vitis-idaea has been suggested to be frost resistant through the tolerance of extracellular ice and mechanisms involving the $C$-repeat binding factor $(C B F)$, rather than by modifying the fatty acid composition of cell membranes to increase their rigidity which is a common frost resistance mechanism in other plants, including the evergreen Empetrum nigrum (Bokhorst et al. 2017; Sklenár 2017). Therefore, the high electrolyte leakage values we found in $V$. vitis-idaea in both spring and summer may be due to the lack of a temperature response of membrane fatty acid composition. Other mechanisms likely act to keep frost damage at a similar level in spring, especially after early snowmelt, compared to summer, in order to avert the negative effects of increased frost events early in the spring.

\section{The potential of Vaccinium vitis-idaea to resist the effects of changes in snowmelt timing}

Winter conditions are predicted to become harsher for plants in northern Finland, with less snow, shorter duration of snow cover and more frost exposure by 2099 compared to the normal period (1981-2010, Jylhä et al. 2009; Räisänen and Eklund 2012). The speed of these changes requires that 
Fig. 5 The relative electrolyte leakage (REL) in Vaccinium vitis-idaea (mean $\pm \mathrm{SE}$ ) along a continuous gradient of snowmelt timing (SnowmeltDOY) during spring (measured shortly after snowmelt, black) and summer (measured in July, grey) above the treeline on mount Saana, Kilpisjärvi. Measurements were taken at two different mountain slope aspects (North and South sites) in $\mathbf{a} 2015$ and $\mathbf{b}$ 2016. The lines represent the modelled regression line for each site and season. The symbols represent the categories of snowmelt timing in Gehrmann et al. (2018) $($ Early $=$ circle, $\mathrm{Mid}=$ triangle, Late $=$ square)
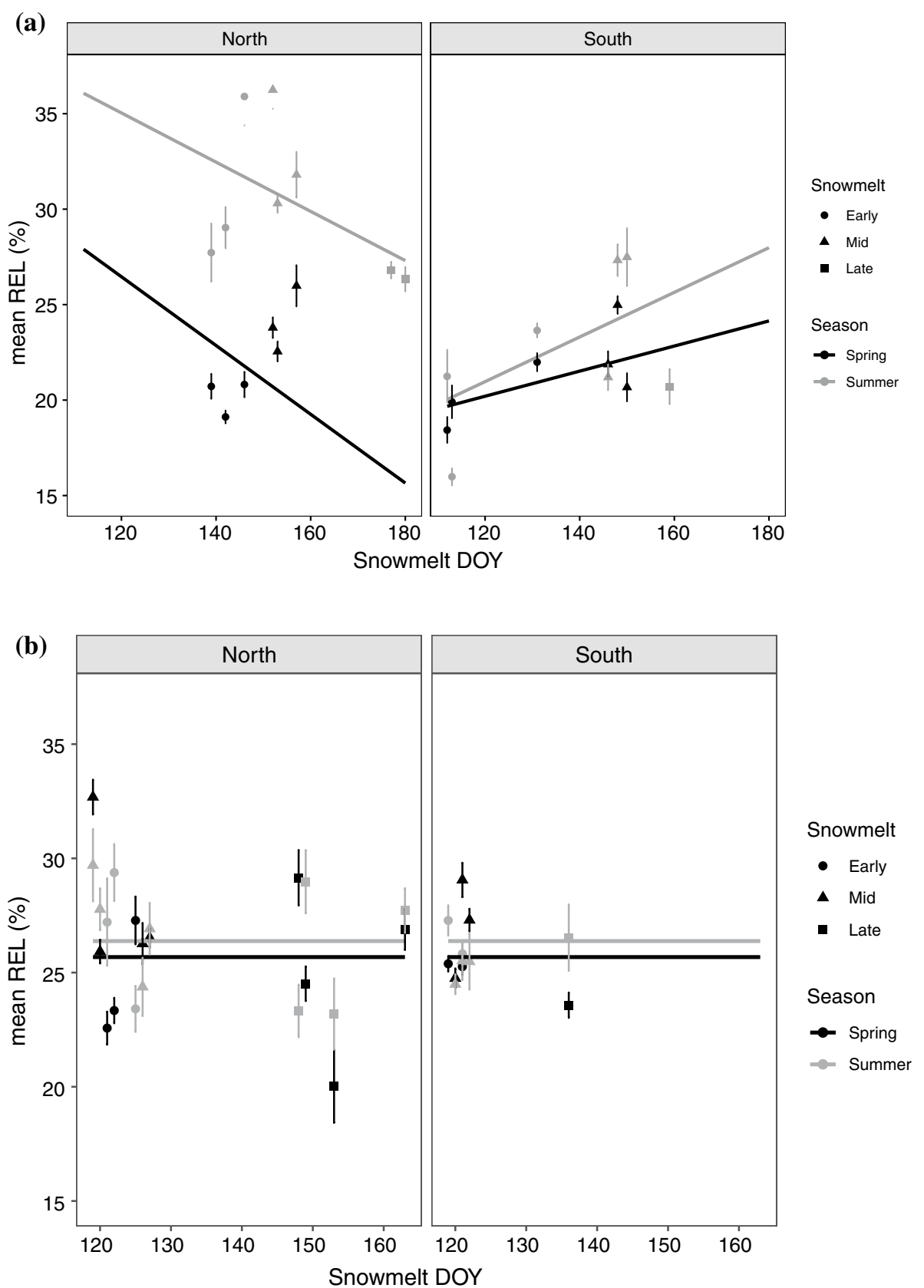

local plant populations either migrate to nearby suitable climate niches or are acclimatised to strongly varying climate conditions. In this study, we addressed these mechanisms simultaneously and show that $V$. vitis-idaea benefits from a combination of the large microclimate heterogeneity in its habitat and its local acclimation to microclimatic variation.

Our study and other published results reveal that subArctic and alpine habitats comprise large microclimate variability which create a buffer against regional climate change (Scherrer and Körner 2010, 2011; Ford et al. 2013). In a study of grassland species in the UK, such heterogeneity in the microclimate allowed the preservation of sufficiently cold habitats during a rise in temperature over 30 years which allowed plants to persist in the colder microclimates rather than go extinct (Maclean et al. 2015). We found that the differences in snow conditions and frost exposure, which exist at a scale of a few metres in this heterogeneous sub-Arctic alpine landscape, correspond in magnitude to projected climate changes. This suggests that even if snow conditions change dramatically in the future, patches with current day snow conditions might persist, allowing $V$. vitis-idaea to migrate to a suitable microclimate over a short distance. 
Many cold-climate plant species have been subjected to repeated periods of glaciation and warming over their evolutionary history, which led them to retain high intra-specific genetic diversity and phenotypic plasticity. This allows populations and species as a whole to be pre-adapted to different climates (Crawford and Abbott 1994). Our results suggest that $V$. vitis-idaea does not suffer detrimental effects from the exposure to large gradients in snowmelt timing and frost, as shown by its persistence along the microclimatic gradient and the low variation in cell damage. We also showed that the amount of reduction in potential yield of PSII in the springtime is related to the timing of snowmelt and fully reversible, indicating a large degree of phenotypic plasticity in this population and a high capacity to cope with the prevailing climate conditions.

However, other sub-Arctic plant species with a higher affinity for snow may be more sensitive to early snowmelt than $V$. vitis-idaea, which survives across a wide range of snow conditions (Wipf et al. 2009; Palacio et al. 2015). Extreme weather events, such as sudden winter warming, pose a greater risk to plants than gradual climate changes, because the fast changes only allow for phenotypic plastic responses instead of evolutionary genetic adaptation. The effect of extreme weather events on plants can range from simple stress responses, such as increased light stress on photosystem II, which we observed in mid-melting plots in the warm spring in 2016, to increased mortality. These responses can lead to decreased biomass and productivity, collectively termed "Arctic browning", which can eventually result in a severe decrease in net ecosystem exchange (Treharne et al. 2019). Despite the high microclimatic heterogeneity in our study site and the persistence of $V$. vitisidaea in this environment, extreme weather events could still have implications for $\mathrm{CO}_{2}$ exchange if they increase in severity and frequency. At the same time, too high plasticity can become maladaptive if it prevents genetic adaptation to a new climate (Benito Garzón et al. 2019). More insight is therefore needed into the plasticity of stress responses, especially along heterogeneous environmental gradients.

Acknowledgements Open access funding provided by Umeå University. The staff at Kilpisjärvi Biological Station provided practical support for the fieldwork and knowledge about the local flora. Che Liu, Sannimari Käärmelahti and Katja Vrabec assisted with the field observations. We thank T. Matthew Robson and Alexey Shapiguzov (Organismal and Evolutionary Biology Research Programme, University of Helsinki) for helpful comments on the manuscript. Miska Luoto (Department of Geosciences and Geography) facilitated the selection of the study sites and provided insightful advice on the project. Pedro J. Aphalo gave advice on statistical testing and $\mathrm{R}$ programming. STRANG data used here are from the Swedish Meteorological and Hydrological Institute (SMHI), and were produced with support from the Swedish Radiation Protection Authority and the Swedish Environmental Agency. This study was funded by grants from the Doctoral Programme in Plant Science (University of Helsinki), the Finnish Society of Forest Sciences, Nordenskiöld-samfundet, Societas pro Fauna et Flora Fennica and Oskar Öflunds Stiftelse to FG.

\section{Compliance with ethical standards}

Conflict of interest The authors declare that they have no conflict of interest.

Open Access This article is licensed under a Creative Commons Attribution 4.0 International License, which permits use, sharing, adaptation, distribution and reproduction in any medium or format, as long as you give appropriate credit to the original author(s) and the source, provide a link to the Creative Commons licence, and indicate if changes were made. The images or other third party material in this article are included in the article's Creative Commons licence, unless indicated otherwise in a credit line to the material. If material is not included in the article's Creative Commons licence and your intended use is not permitted by statutory regulation or exceeds the permitted use, you will need to obtain permission directly from the copyright holder. To view a copy of this licence, visit http://creativecommons.org/licenses/by/4.0/.

\section{References}

Aalto J, Riihimäki H, Meineri E, Hylander K, Luoto M (2017) Revealing topoclimatic heterogeneity using meteorological station data. Int J Climatol 37:544-556. https://doi.org/10.1002/joc.5020

Aalto J, Scherrer D, Lenoir J, Guisan A, Luoto M (2018) Biogeophysical controls on soil-atmosphere thermal differences: implications on warming Arctic ecosystems. Environ Res Lett 13:074003. https ://doi.org/10.1088/1748-9326/aac83e

Adams WW III, Demmig-Adams B, Rosenstiel TN, Brightwell AK, Ebbert V (2002) Photosynthesis and photoprotection in overwintering plants. Plant Biol 4:545-557. https://doi. org/10.1055/s-2002-35434

Adams WW III, Zarter CR, Ebbert V, Demmig-Adams B (2004) Photoprotective strategies of overwintering evergreens. Bioscience 54:41-49. https://doi.org/10.1641/00063568(2004)054[0041:PSOOE]2.0.CO;2

AMAP (2017) Snow, Water, Ice and Permafrost in the Arctic (SWIPA) (2017). Arctic Monitoring and Assessment Programme (AMAP), Oslo

Bajji M, Kinet J-M, Lutts S (2001) The use of the electrolyte leakage method for assessing cell membrane stability as a water stress tolerance test in durum wheat. Plant Growth Regul 00:1-10. https ://doi.org/10.1023/A:1014732714549

Benito Garzón M, Robson TM, Hampe A (2019) $\Delta$ TraitSDM: species distribution models that account for local adaptation and phenotypic plasticity. New Phytol. https://doi.org/10.1111/nph.15716

Billings WD, Bliss LC (1959) An alpine snowbank environment and its effects on vegetation, plant development and productivity. Ecology 40:388-397

Bokhorst SF, Bjerke JW, Tømmervik H, Callaghan TV, Phoenix GK (2009) Winter warming events damage sub-Arctic vegetation: consistent evidence from an experimental manipulation and a natural event. J Ecol 97:1408-1415. https://doi.org/10.111 $1 /$ j.1365-2745.2009.01554.x

Bokhorst S, Bjerke JW, Davey MP, Taulavuori K, Taulavuori E, Laine K, Callaghan TV, Phoenix GK (2010) Impacts of extreme winter warming events on plant physiology in a sub-Arctic heath community. Physiol Plant 140:128-140. https://doi.org/10.111 1/j.1399-3054.2010.01386.x 
Bokhorst S, Bjerke JW, Street LE, Callaghan TV, Phoenix GK (2011) Impacts of multiple extreme winter warming events on sub-Arctic heathland: phenology, reproduction, growth, and $\mathrm{CO}_{2}$ flux responses. Glob Chang Biol 17:2817-2830. https://doi.org/10.11 11/j.1365-2486.2011.02424.x

Bokhorst S, Jaakola L, Karppinen K, Edvinsen GK, Mæhre HK, Bjerke JW (2017) Contrasting survival and physiological responses of sub-Arctic plant types to extreme winter warming and nitrogen. Planta 247:635-648. https://doi.org/10.1007/s00425-017-2813-6

Callaghan TV, Johansson M, Brown RD, Groisman PY, Labba N, Radionov V, Barry RG, Bulygina ON, Essery RLH, Frolov DM, Golubev VN, Grenfell TC, Petrushina MN, Razuvaev VN, Robinson DA, Romanov P, Shindell D, Shmakin AB, Sokratov SA, Warren S, Yang D (2011) The changing face of Arctic snow cover: a synthesis of observed and projected changes. Ambio 40:17-31. https://doi.org/10.1007/s13280-011-0212-y

Crawford RMM (2008) Cold climate plants in a warmer world. Plant Ecol Divers 1:285-297. https://doi.org/10.1080/1755087080 2407332

Crawford RMM, Abbott RJ (1994) Pre-adaptation of Arctic plants to climate change. Bot Acta 107:271-278. https://doi. org/10.1111/j.1438-8677.1994.tb00796.x

Ensminger I, Sveshnikov D, Campbell DA, Funk C, Jansson S, Lloyd J, Shibistova O, Öquist G (2004) Intermittent low temperatures constrain spring recovery of photosynthesis in boreal Scots pine forests. Glob Chang Biol 10:995-1008. https://doi.org/10.111 1/j.1365-2486.2004.00781.x

Ensminger I, Schmidt L, Lloyd J (2008) Soil temperature and intermittent frost modulate the rate of recovery of photosynthesis in Scots pine under simulated spring conditions. New Phytol 177:428-442. https://doi.org/10.1111/j.1469-8137.2007.02273 . $\mathrm{X}$

Ford KR, Ettinger AK, Lundquist JD, Raleigh MS, Hille Ris Lambers J (2013) Spatial heterogeneity in ecologically important climate variables at coarse and fine scales in a high-snow mountain landscape. PLoS ONE 8:e65008. https://doi.org/10.1371/journ al.pone.0065008

Gehrmann F, Hänninen H, Liu C, Saarinen T (2018) Phenological responses to small-scale spatial variation in snowmelt timing reveal compensatory and conservative strategies in subarctic-alpine plants. Plant Ecol Divers 10:453-468. https://doi. org/10.1080/17550874.2018.1428693

Gerland S, Liston GE, Winther J-G, Ørbaek JB, Ivanov BV (2000) Attenuation of solar radiation in Arctic snow: field observations and modelling. Ann Glaciol 31:364-368. https://doi. org/10.3189/172756400781820444

Graae BJ, De Frenne P, Kolb A, Brunet J, Chabrerie O, Verheyen K, Pepin N, Heinken T, Zobel M, Shevtsova A, Nijs I, Milbau A (2012) On the use of weather data in ecological studies along altitudinal and latitudinal gradients. Oikos 121:3-19. https://doi. org/10.1111/j.1600-0706.2011.19694.x

Graae BJ, Vandvik V, Armbruster WS, Eiserhardt WL, Svenning J-C, Hylander K, Ehrlén J, Speed JDM, Klanderud K, Bråthen KA, Milbau A, Opedal ØH, Alsos IG, Ejrnæs R, Bruun HH, Birks HJB, Westergaard KB, Birks HH, Lenoir J (2018) Stay or go how topographic complexity influences alpine plant population and community responses to climate change. Perspect Plant Ecol Evol Syst 30:41-50. https://doi.org/10.1016/j.ppees.2017.09.008

Huner NPA, Öquist G, Hurry VM, Krol M, Falk S, Griffith M (1993) Photosynthesis, photoinhibition and low temperature acclimation in cold tolerant plants. Photosynth Res 37:19-39. https://doi. org/10.1007/BF02185436

Inouye DW (2000) The ecological and evolutionary significance of frost in the context of climate change. Ecol Lett 3:457-463. https ://doi.org/10.1046/j.1461-0248.2000.00165.x
Inouye DW (2008) Effects of climate change on phenology, frost damage, and floral abundance of montane wildflowers. Ecology 89:353-362. https://doi.org/10.1890/06-2128.1

Jylhä K, Ruosteenoja K, Räisänen J, Venäläinen A, Tuomenvirta H, Ruokolainen L, Saku S, Seitola T (2009) Arvioita Suomen muuttuvasta ilmastosta sopeutumistutkimuksia varten - ACCLIMhankkeen raportti 2009. (The changing climate in Finland: estimates for adaptation studies, ACCLIM project report 2009.). Finnish Meterological Institute, Helsinki

Kimball SL, Bennett BD, Salisbury FB (1973) The growth and development of montane species at near-freezing temperatures. Ecology $54: 168-173$

Körner C (2003) Alpine plant life: functional plant ecology of high mountain ecosystems. Springer, Berlin

Lembrechts JJ, Nijs I, Lenoir J (2018) Incorporating microclimate into species distribution models. Ecography 42:1-13. https://doi. org/10.1111/ecog.03947

Lenoir J, Hattab T, Pierre G (2017) Climatic microrefugia under anthropogenic climate change: implications for species redistribution. Ecography 40:253-266. https://doi.org/10.1111/ecog.02788

Lenth R (2020) Emmeans: estimated marginal means, aka least-squares means. R package version 1(4):6

Li X-P, Björkman O, Shih C, Grossman AR, Rosenquist M, Jansson S, Niyogi KK (2000) A pigment-binding protein essential for regulation of photosynthetic light harvesting. Nature 403:391-395. https ://doi.org/10.1038/35000131

Lundell R, Saarinen T, Åström H, Hänninen H (2008) The boreal dwarf shrub Vaccinium vitis-idaea retains its capacity for photosynthesis through the winter. Botany 86:491-500. https://doi.org/10.1139/ B08-022

Lundell R, Saarinen T, Hänninen H (2010) Effects of snowmelt on the springtime photosynthesis of the evergreen dwarf shrub Vaccinium vitis-idaea. Plant Ecol Divers 3:121-130. https://doi. org/10.1080/17550874.2010.497195

Luoranen J, Repo T, Lappi J (2004) Assessment of the frost hardiness of shoots of silver birch (Betula pendula) seedlings with and without controlled exposure to freezing. Can J For Res 34:1108-1118. https://doi.org/10.1139/x03-285

Maclean IMD, Hopkins JJ, Bennie J, Lawson CR, Wilson RJ (2015) Microclimates buffer the responses of plant communities to climate change. Glob Ecol Biogeogr 24:1340-1350. https://doi. org/10.1111/geb.12359

Maxwell K, Johnson GN (2000) Chlorophyll fluorescence: a practical guide. J Exp Bot 51:659-668. https://doi.org/10.1093/ $\mathrm{jxb} / 51.345 .659$

McKay GA, Gray DM (1981) The distribution of snowcover. Principles, processses, management and use. In: Gray DM, Male DH (eds) Handbook of snow. Pergamon Press Toronto, Elmsford, pp 153-190

Míguez F, Fernández-Marín B, Becerril JM, García-Plazaola JI (2015) Activation of photoprotective winter photoinhibition in plants from different environments: A literature compilation and metaanalysis. Physiol Plant 155:414-423. https://doi.org/10.1111/ ppl.12329

Neuner G, Ambach D, Aichner K (1999) Impact of snow cover on photoinhibition and winter desiccation in evergreen Rhododendron ferrugineum leaves during subalpine winter. Tree Physiol 19:725-732. https://doi.org/10.1093/treephys/19.11.725

Niittynen P, Luoto M (2017) The importance of snow in species distribution models of arctic vegetation. Ecography 40:1-13. https ://doi.org/10.1111/ecog.03348

Niskanen AKJ, Heikkinen RK, Mod HK, Väre H, Luoto M (2017a) Improving forecasts of arctic-alpine refugia persistence with landscape-scale variables. Geogr Ann Ser A 99:2-14. https://doi. org/10.1080/04353676.2016.1256746 
Niskanen AKJ, Luoto M, Väre H, Heikkinen RK (2017b) Models of Arctic-alpine refugia highlight importance of climate and local topography. Polar Biol 40:489-502. https://doi.org/10.1007/s0030 0-016-1973-3

Ögren E (1996) Premature dehardening in Vaccinium myrtillus during a mild winter: a cause for winter dieback? Funct Ecol 10:724-732

Öquist G, Huner NPA (2003) Photosynthesis of overwintering evergreen plants. Annu Rev Plant Biol 54:329-355. https://doi. org/10.1146/annurev.arplant.54.072402.115741

Outcalt SI, Nelson FE, Hinkel KM (1990) The zero-curtain effect: Heat and mass transfer across an isothermal region in freezing soil. Water Resour Res 26:1509-1516. https://doi.org/10.1029/ WR026i007p01509

Palacio S, Lenz A, Wipf S, Hoch G, Rixen C (2015) Bud freezing resistance in alpine shrubs across snow depth gradients. Environ Exp Bot 118:95-101. https://doi.org/10.1016/j.envex pbot.2015.06.007

Pinheiro J, Bates D, DebRoy S, Sarkar D, R Core Team (2020) nlme: Linear and Nonlinear Mixed Effects Models. R package version 3.1-147

Pirinen P, Simola H, Aalto J, Kaukoranta J-P, Karlsson P, Ruuhela R (2012) Climatological statistics of Finland 1981-2010. Finnish Meterological Institute, Helsinki

Preece C, Phoenix GK (2013) Responses of sub-arctic dwarf shrubs to low oxygen and high carbon dioxide conditions. Environ Exp Bot 85:7-15. https://doi.org/10.1016/j.envexpbot.2012.06.003

R Core Team (2020) R: a language and environment for statistical computing. R Foundation for Statistical Computing, Vienna

Räisänen J, Eklund J (2012) 21st Century changes in snow climate in Northern Europe: a high-resolution view from ENSEMBLES regional climate models. Clim Dyn 38:2575-2591. https://doi. org/10.1007/s00382-011-1076-3

Ritchie AJC (1955) Vaccinium vitis-idaea L. J Ecol 43:701-708

Rosenfeld D, Sherwood S, Wood R, Donner L (2014) Climate effects of aerosol-cloud interactions. Science 343:379-381. https://doi. org/10.1126/science. 1247490

Saarinen T, Lundell R (2010) Overwintering of Vaccinium vitisidaea in two sub-Arctic microhabitats: a reciprocal transplantation experiment. Polar Res 29:38-45. https://doi.org/10.111 $1 / \mathrm{j} .1751-8369.2010 .00152 . x$

Saarinen T, Rasmus S, Lundell R, Kauppinen O-K, Hänninen H (2015) Photosynthetic and phenological responses of dwarf shrubs to the depth and properties of snow. Oikos 125:001-010. https://doi. org/10.1111/oik.02233

Scherrer D, Körner C (2010) Infra-red thermometry of alpine landscapes challenges climatic warming projections. Glob Chang Biol 16:2602-2613. https://doi.org/10.1111/j.1365-2486.2009.02122.x

Scherrer D, Körner C (2011) Topographically controlled thermalhabitat differentiation buffers alpine plant diversity against climate warming. J Biogeogr 38:406-416. https://doi.org/10.111 1/j.1365-2699.2010.02407.x

Scherrer D, Schmid S, Körner C (2011) Elevational species shifts in a warmer climate are overestimated when based on weather station data. Int J Biometeorol 55:645-654. https://doi.org/10.1007/ s00484-010-0364-7

Semenchuk PR, Elberling B, Cooper EJ (2013) Snow cover and extreme winter warming events control flower abundance of some, but not all species in high arctic Svalbard. Ecol Evol 3:2586-2599. https://doi.org/10.1002/ece3.648
Sklenář P (2017) Seasonal variation of freezing resistance mechanisms in north-temperate alpine plants. Alp Bot 127:31-39. https://doi. org/10.1007/s00035-016-0174-6

Solanki T, Aphalo PJ, Neimane S, Hartikainen SM, Pieristè M, Shapiguzov A, Porcar-Castell A, Atherton J, Heikkilä A, Robson TM (2019) UV-screening and springtime recovery of photosynthetic capacity in leaves of Vaccinium vitis-idaea above and below the snow pack. Plant Physiol Biochem 134:40-52. https://doi. org/10.1016/j.plaphy.2018.09.003

Starr G (2001) A multiscale assessment of physiological processes in arctic tundra plants under natural and simulated climate change scenarios. Dissertation, Florida International University

Starr G, Oberbauer SF (2003) Photosynthesis of arctic evergreens under snow: implications for tundra ecosystem carbon balance. Ecology 84:1415-1420. https://doi.org/10.1890/02-3154

Starr G, Oberbauer SF, Ahlquist LE (2008) The photosynthetic response of Alaskan tundra plants to increased season length and soil warming. Arctic Antarct Alp Res 40:181-191. https://doi. org/10.1657/1523-0430(06-015)

Sutinen M-L, Palta JP, Reich PB (1992) Seasonal differences in freezing stress resistance of needles of Pinus nigra and Pinus resinosa: evaluation of the electrolyte leakage method. Tree Physiol 11:241-254. https://doi.org/10.1093/TREEPHYS/11.3.241

Tahkokorpi M, Taulavuori K, Laine K, Taulavuori E (2007) Aftereffects of drought-related winter stress in previous and current year stems of Vaccinium myrtillus L. Environ Exp Bot 61:85-93. https://doi.org/10.1016/j.envexpbot.2007.03.003

Taschler D, Neuner G (2004) Summer frost resistance and freezing patterns measured in situ in leaves of major alpine plant growth forms in relation to their upper distribution boundary. Plant Cell Environ 27:737-746. https://doi.org/10.1111/j.1365-3040.2004.01176.x

Taulavuori KMJ, Taulavuori EB, Skre O, Nilsen J, Igeland B, Laine KM (2004) Dehardening of mountain birch (Betula pubescens ssp. czerepanovii) ecotypes at elevated winter temperatures. New Phytol 162:427-436. https://doi.org/10.1111/j.1469-8137.2004.01042 .X

Taulavuori KMJ, Bauer E, Taulavuori E (2011) Overwintering stress of Vaccinium vitis-idaea in the absence of snow cover. Environ Exp Bot 72:397-403. https://doi.org/10.1016/j.envexpbot.2011.02.009

Treharne R, Bjerke JW, Tømmervik H, Stendardi L, Phoenix GK (2019) Arctic browning: Impacts of extreme climatic events on heathland ecosystem $\mathrm{CO}_{2}$ fluxes. Glob Chang Biol 25:489-503. https://doi.org/10.1111/gcb.14500

Vikhamar-Schuler D, Isaksen K, Haugen JE, Tømmervik H, Luks B, Schuler TV, Bjerke JW (2016) Changes in winter warming events in the nordic arctic region. J Clim 29:6223-6244. https:// doi.org/10.1175/JCLI-D-15-0763.1

Wipf S, Rixen C, Mulder CPH (2006) Advanced snowmelt causes shift towards positive neighbour interactions in a subarctic tundra community. Glob Chang Biol 12:1496-1506. https://doi.org/10.111 1/j.1365-2486.2006.01185.x

Wipf S, Stoeckli V, Bebi P (2009) Winter climate change in alpine tundra: Plant responses to changes in snow depth and snowmelt timing. Clim Change 94:105-121. https://doi.org/10.1007/s1058 4-009-9546-x

Publisher's Note Springer Nature remains neutral with regard to jurisdictional claims in published maps and institutional affiliations. 